\title{
Bone morphogenetic protein-2 and -9 regulate the interaction of insulin-like growth factor-I with growth plate chondrocytes
}

\author{
TOSHIAKI TAKAHASHI ${ }^{1,3}$, ELISABETH A. MORRIS ${ }^{2}$ and STEPHEN B. TRIPPEL ${ }^{1,4}$ \\ ${ }^{1}$ Orthopaedic Research Laboratories, Massachusetts General Hospital, Harvard Medical School, 55 Fruit Street, \\ Boston, MA 02114; ${ }^{2}$ Wyeth Research, Department of Women's Health and Musculoskeletal Biology, \\ 87 Cambridge Park Drive, Cambridge, MA 02140, USA; ${ }^{3}$ Department of Bone and Joint Surgery, \\ Ehime University Graduate School of Medicine, Shitsukawa, Toon, Ehime 791-0295, Japan; \\ ${ }^{4}$ Department of Orthopaedic Surgery, Indiana University School of Medicine, \\ 541 Clinical Drive, Suite 600, Indianapolis, IN 46202-5111, USA
}

Received February 20, 2007; Accepted March 23, 2007

\begin{abstract}
Insulin-like growth factor-I (IGF-I) is thought to play an important role in skeletal growth and development through its mitogenic and anabolic effects on epiphyseal growth plate chondrocytes. The bone morphogenetic proteins (BMPs) have been shown to promote endochondral osteogenesis, and some members of the BMP family, including BMP-2 and BMP-9, have anabolic effects on chondrocyte metabolism. We tested the hypothesis that BMP-2 and BMP-9 interact with IGF-I to modulate growth plate chondrocyte mitotic activity. IGF-I, but neither BMP-2 nor BMP-9, stimulated chondrocyte DNA synthesis. However, both BMP-2 and BMP-9 augmented the mitogenic action of IGF-I. BMP-2, but not BMP-9 increased IGF-I binding to growth plate chondrocytes in kinetic studies. In affinity labeling studies, ${ }^{125}$ I-IGF-I predominantly labeled an $\mathrm{Mr} \sim 135-\mathrm{kDa}$ moiety, consistent with the $\alpha$ subunit of the type 1 IGF receptor and an $\mathrm{Mr} \sim 250-\mathrm{kDa}$ moiety consistent with the type 2 IGF receptor. ${ }^{125} \mathrm{I}$-IGF-I labeling also appeared at $\mathrm{Mr} \sim 43 \mathrm{kDa}$, consistent with ${ }^{125}$ I-IGF-I binding to insulin-like growth binding protein-3. Treatment of chondrocytes with BMP-2, but not with BMP-9, increased the intensity of the $\mathrm{Mr}$ $\sim 135-\mathrm{kDa}$ band and decreased the intensity of the $\mathrm{Mr} \sim 43-\mathrm{kDa}$ band. Taken together, these data suggest that the BMPs may modulate the action of IGF-I via the type 1 IGF receptor and/ or IGF binding proteins.
\end{abstract}

Correspondence to: Dr Toshiaki Takahashi, Department of Bone and Joint Surgery, Ehime University Graduate School of Medicine, Shitsukawa, Toon, Ehime 791-0295, Japan

E-mail: takahast@m.ehime-u.ac.jp

Key words: bone morphogenetic proteins, insulin-like growth factor-I, growth plate chondrocytes

\section{Introduction}

The normal growth and differentiation of cartilage is regulated by multiple cell-signaling polypeptides. Among these are insulin-like growth factor I (IGF-I) and members of the bone morphogenetic protein (BMP) family. IGF-I is mitogenic for growth plate chondrocytes and stimulates chondrocyte synthesis of matrix macromolecules, including proteoglycan and collagen (1-3). IGF-I is at least partly responsible for skeletal growth and development in vivo through its actions on the epiphyseal growth plate (4). The bone morphogenetic proteins are members of the transforming growth factor- $\beta$ superfamily. In skeletal tissues they play diverse roles ranging from patterning to differentiation (5). BMP-2 and BMP-9 are capable of initiating the full sequence of endochondral osteogenesis in ectopic sites, a process that recapitulates the endochondral osteogenesis regulated by IGF-I in the growth plate. IGF-I, BMP-2 and BMP-9 have all been shown to stimulate the synthesis of proteoglycan, a major constituent of cartilage matrix $(6,7)$.

IGF-I is thought to exert its biological effect on chondrocytes by binding to the type 1 IGF receptor, a member of the protein tyrosine kinase receptor family. This receptor exists as a heterotetrameric complex composed of disulfide-linked subunits. Two paired extracellular $\alpha$ subunits contain the IGF binding site and two paired transmembrane $\beta$ subunits possess the kinase domains (8). IGF-I also binds to a monomeric type 2 IGF receptor that lacks kinase activity and may serve to modulate IGF availability (9). IGF-I action is also influenced by insulin-like growth factor binding proteins (IGFBPs) (10). Of the six canonical members of the IGFBP family, IGFBP-3 is present in greatest abundance in serum where it serves to increase the half-life of IGF-I (11). The action of IGFBP-3 is context-dependent and may inhibit or augment the effects of IGF-I (12). BMP receptors are members of the serine/threonine kinase receptor family, contrasting them with the IGF-I receptor $(12,13)$.

BMPs (14-16) and IGF-I (17) are present in cartilage. It is unlikely that IGF-I and BMP-2 or BMP-9 regulate cartilage independently. In order to understand the role of these factors 
in cartilage regulation, it is perhaps as important, if not more important, to understand their interaction as it is to understand their individual effects. In the present study we tested the hypothesis that BMP-2 and BMP-9 interact with IGF-I to modulate growth plate chondrocyte function.

\section{Materials and methods}

Reagents and growth factors. Recombinant human BMP-2 and BMP-9 were purified from Chinese hamster ovary cells as previously described (17). ${ }^{125} \mathrm{I}$-labeled IGF-I ( $\left.{ }^{125} \mathrm{I}-\mathrm{IGF}-\mathrm{I}\right)$ was the kind gift of Dr L.E. Underwood and Dr J.J. Van Wyk (University of North Carolina-Chapel Hill). DMEM and MCDB-105 culture media were from Gibco Life Technologies (Grand Island, NY). Bovine serum albumin, screened by radioimmunoassay for IGF-I content $<20 \mathrm{ng} / \mathrm{ml}$, was from Sigma (St. Louis, MO), and fetal bovine serum (FBS) was from Invitrogen Corp. (Carlsbad, CA). Pluronic F-68 was from BASF Corp. (Parsippany, NJ). Collagenase was from Worthington Biochemical Corporation (Lakewood, NJ). Acrylamide gel was from Novex (San Diego, CA), and ${ }^{3} \mathrm{H}-$ thymidine was from New England Nuclear Life Science Products, Inc. (Boston, MA).

Chondrocyte isolation. Neonatal bovine distal radio-ulnar growth plate cartilage was harvested under sterile conditions, diced into $\sim 2$-mm cubes, and incubated in DMEM containing $0.1 \%$ collagenase and antibiotics overnight in spinner bottles at $37^{\circ} \mathrm{C}, 5 \% \mathrm{CO}_{2}$. Undigested matrix was removed by filtration through $150-\mu \mathrm{m}$ pore size nylon mesh followed by centrifugation at $700 \mathrm{x} g$ for 6 min over a Ficoll-Hypaque (10/11\%) gradient. The isolated cells were washed with phosphatebuffered saline solution (PBS), and re-suspended at $0.5 \times 10^{6}$ cells/ $\mathrm{ml}$ in DMEM with $2 \%$ FBS, antibiotics and $0.1 \%$ pluronic F-68 for $24 \mathrm{~h}$.

Binding of ${ }^{125}$ I-labeled IGF-I to growth plate chondrocytes. Cells were washed and re-suspended in DMEM containing antibiotics and graded concentrations of rhBMP-2 (0-300 ng/ $\mathrm{ml})\left(0-9.4 \times 10^{-9} \mathrm{M}\right)$ or rhBMP-9 $(0-100 \mathrm{ng} / \mathrm{ml})\left(0-3.13 \times 10^{-9} \mathrm{M}\right)$ for $24 \mathrm{~h}$. For competition binding studies, cells were washed twice in binding medium consisting of bicarbonate-free DMEM with $20 \mathrm{mM}$ HEPES, pH 7.8, and $1 \%$ bovine serum albumin at $4^{\circ} \mathrm{C}$, and aliquots of re-suspended cells were incubated in binding medium in the presence of $50,000 \mathrm{cpm} /$ $3 \times 10^{6}$ cells, ${ }^{125}$ I-IGF-I (specific activity $382-427 \mu \mathrm{Ci} / \mu \mathrm{g}$ ) and graded concentrations of unlabeled IGF-I $\left(0,1 \times 10^{-11}, 1 \times 10^{-10}\right.$, $1 \times 10^{-9}, 1 \times 10^{-8}$ and $2 \times 10^{-7} \mathrm{M}$ ) in a total volume of $0.4 \mathrm{ml}$ for $24 \mathrm{~h}$ at $15^{\circ} \mathrm{C}$ in duplicate. Bound ligand was separated from free ligand by centrifugation for $1.5 \mathrm{~min}$ at $9500 \mathrm{x} \mathrm{g}$ followed by a wash with ice-cold binding medium and repeat centrifugation. The cell pellet was counted in a $\gamma$-spectrometer (Auto Gamma, Packard Instruments, Meriden, CT). Nonspecific binding was defined as binding in the presence of an excess $\left(2 \times 10^{-7} \mathrm{M}\right)$ of unlabeled IGF-I. Specific binding was defined as total binding minus nonspecific binding and normalized to that of the controls ( $0 \mathrm{M}$ unlabeled IGF-I).

Cross-linking of ${ }^{125}$ I-IGF-I to growth plate chondrocytes. Chondrocytes isolated as described above were incubated in the absence of BMP or in the presence of $300 \mathrm{ng} / \mathrm{ml}\left(9.4 \times 10^{-9} \mathrm{M}\right)$ BMP-2 or $300 \mathrm{ng} / \mathrm{ml}\left(9.4 \times 10^{-9} \mathrm{M}\right)$ BMP-9 in DMEM with antibiotics in a spinner bottle at $37^{\circ} \mathrm{C}$ for $16 \mathrm{~h}$. Cells were washed twice in ice-cold binding medium, and aliquots of $8 \times 10^{6}$ cells were incubated with $0.5 \times 10^{6} \mathrm{cpm}$ of ${ }^{125} \mathrm{I}-\mathrm{IGF}-\mathrm{I}$ in the absence or presence of unlabeled IGF-I $\left(2 \times 10^{-7} \mathrm{M}\right)$ in a total volume of $0.5 \mathrm{ml}$ at $4^{\circ} \mathrm{C}$. After $24 \mathrm{~h}$, freshly solubilized disuccinimidylsuberate (DSS) in dimethyl sulfoxide (DMSO) was added in a final concentration of $0.5 \mathrm{mM}$. After $30 \mathrm{~min}$ at $22^{\circ} \mathrm{C}$, the reaction was quenched with an excess $(0.25 \mathrm{M})$ of $\mathrm{NH}_{4} \mathrm{Br}$. The reaction mixture was diluted with $0.8 \mathrm{ml}$ of PBS at $4^{\circ} \mathrm{C}$, and the cells were centrifuged at $9500 \times \mathrm{g}$ for $15 \mathrm{~min}$ at $4^{\circ} \mathrm{C}$, and washed with $1 \mathrm{ml}$ of cold PBS.

Cell pellets were dissolved in $100 \mu 1$ of $1 \mathrm{X}$ sample buffer (SDS $4 \mathrm{~g}$, Tris $1.51 \mathrm{~g}$, bromphenol blue $2 \mathrm{mg}$, glycerol $40 \mathrm{ml}$, and $\mathrm{H}_{2} \mathrm{O} 160 \mathrm{ml}$ ). In the reducing condition, a $5 \%$ volume of 2-mercaptoethanol was added. In both reducing and nonreducing conditions, cells were boiled with sample buffer at $95^{\circ} \mathrm{C}$ for $2 \mathrm{~min}$. Samples were passed through a 22-gauge needle 15 times and subjected to SDS polyacrylamide gel electrophoresis (PAGE). The SDS PAGE was performed using $10 \%$ acrylamide TG 1.5-mm gel (Novex, San Diego, CA) without SDS. Gels were stained with Coomassie blue, destained, and dried. Autoradiograms were made on Kodak $\mathrm{X}$-omat AR film in the presence of an image-intensifying screen for 7-14 days at $-70^{\circ} \mathrm{C}$ and developed (17).

${ }^{3} H$-thymidine incorporation. Isolated chondrocytes were washed in PBS, plated in DMEM with $10 \%$ FBS and antibiotics at $5 \times 10^{5}$ cells $/ \mathrm{ml}$ in quadruplicate in 96-well plates, and incubated for $24 \mathrm{~h}$ at $37^{\circ} \mathrm{C}$ in an atmosphere of $5 \% \mathrm{CO}_{2}$ in air. The medium was changed to serum-free MCDB-105 medium ( $\mathrm{pH} 7.4$ ) with antibiotics (basal medium) for $24 \mathrm{~h}$, replaced with basal medium containing IGF-I $(0-230 \mathrm{ng} / \mathrm{ml})$ $\left(0-3 \times 10^{-8} \mathrm{M}\right)$; BMP-2 $(0-320 \mathrm{ng} / \mathrm{ml})\left(0-1 \times 10^{-8} \mathrm{M}\right)$; the combination of IGF-I $(0-230 \mathrm{ng} / \mathrm{ml})\left(0-3 \times 10^{-8} \mathrm{M}\right)+$ BMP-2 $(0-320 \mathrm{ng} / \mathrm{ml})\left(0-1 \times 10^{-8} \mathrm{M}\right)$; or the combination of IGF-I $(0-230 \mathrm{ng} / \mathrm{ml})\left(0-3 \times 10^{-8} \mathrm{M}\right)+$ BMP-9 $(0-320 \mathrm{ng} / \mathrm{ml})\left(0-1 \times 10^{-8} \mathrm{M}\right)$ for $48 \mathrm{~h}$. Twenty-four hours before the end of incubation, $8 \mu \mathrm{Ci} / \mathrm{ml}{ }^{3} \mathrm{H}$-thymidine was added. The cells were washed three times with $200 \mu 1$ ice-cold PBS, twice with $200 \mu 1$ icecold 5\% trichloroacetic acid and twice with $200 \mu 1$ 3:1 (volume) ethanol/ethyl ether. The samples were dissolved in $200 \mu 10.3 \mathrm{M} \mathrm{NaOH}$, neutralized with $10 \mu 16 \mathrm{~N} \mathrm{HCI}$ on ice and transferred to scintillation vials. Cytoscint, $4 \mathrm{ml} / \mathrm{vial}$, was added, vortexed, and let stand at room temperature for $24 \mathrm{~h}$. Incorporation of ${ }^{3} \mathrm{H}$-thymidine was determined by liquid scintillation counting (1).

Statistical analysis. Statistical analysis was performed by the Student's t-test for IGF-I, BMP-2 or BMP-9 alone and by two- way ANOVA for combinations of BMPs and IGF-I.

\section{Results}

Binding studies. Specific binding of ${ }^{125} \mathrm{I}-\mathrm{IGF}-\mathrm{I}$ in the absence of unlabeled IGF-I (maximal specific binding) averaged $12.2 \%$ per $3 \times 10^{6}$ cells. Non-specific binding was $\sim 2.4 \%$. Unlabeled IGF-I competed with ${ }^{125}$ I-IGF-I binding to growth plate chondrocytes with $50 \%$ displacement at $\sim 10^{-9} \mathrm{M}$ for 
A

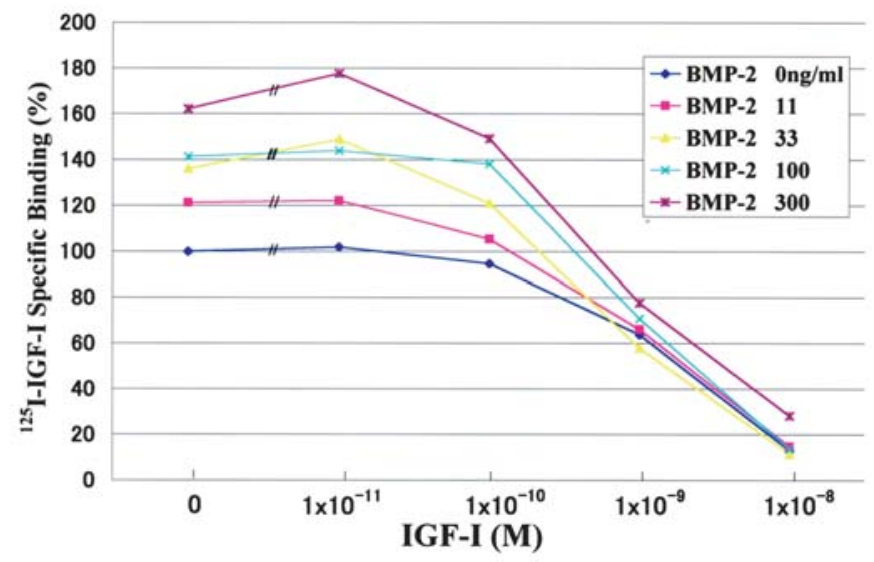

B

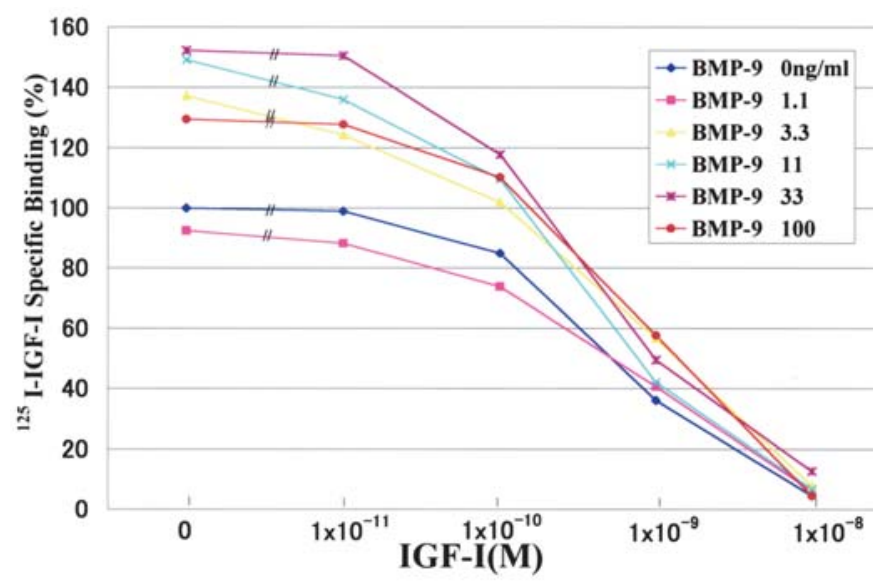

Figure 1. Specific IGF-I binding to growth plate chondrocytes cultured in the presence of graded concentrations of BMP-2 (A) or BMP-9 (B). Specific binding was normalized to the control group (no BMP-2 or -9). Graphs represent one of three independent experiments.

control cells not exposed to BMP (Fig. 1A and B). Incubation of growth plate chondrocytes with BMP-2 for $24 \mathrm{~h}$ increased maximal specific binding of ${ }^{125}$ I-IGF-I by $22 \%(\mathrm{p}=0.627)$, $48 \%(\mathrm{p}=0.036), 43 \%(\mathrm{p}=0.259)$, and $78 \%(\mathrm{p}=0.011)$ at concentrations of $11\left(3.44 \times 10^{-10} \mathrm{M}\right), 33\left(1.04 \times 10^{-9} \mathrm{M}\right), 100$ $\left(3.13 \times 10^{-9} \mathrm{M}\right)$, and $300 \mathrm{ng} / \mathrm{ml}\left(9.4 \times 10^{-9} \mathrm{M}\right)$, respectively $(n=3)$. Incubation of chondrocytes with BMP-9 altered maximal specific binding of ${ }^{125}$ I-IGF-I by $-7 \%(\mathrm{p}=0.478)$, $37 \%(\mathrm{p}=0.101), 49 \%(\mathrm{p}=0.117) 52 \%(\mathrm{p}=0.067)$, and $30 \%$ $(\mathrm{p}=0.621)$ at concentrations of $1.1\left(3.44 \times 10^{-11} \mathrm{M}\right), 3.3$ $\left(1.04 \times 10^{-10} \mathrm{M}\right), 11\left(3.44 \times 10^{-10} \mathrm{M}\right), 33\left(1.04 \times 10^{-9} \mathrm{M}\right)$, and $100 \mathrm{ng} / \mathrm{ml}\left(3.13 \times 10^{-9} \mathrm{M}\right)$, respectively $(\mathrm{n}=3)$.

Cross-linking studies. When growth plate chondrocytes were labeled with ${ }^{125}$ I-IGF-I without prior disulfide bond reduction, ${ }^{125}$ I-IGF-I binding was to species migrating with an apparent $\mathrm{Mr}$ of $>220 \mathrm{kDa}$, consistent with the unreduced forms of the type 1 and type 2 IGF receptors. Under reducing conditions, the majority of ${ }^{125} \mathrm{I}-\mathrm{IGF}-\mathrm{I}$ appeared at $\mathrm{Mr} \sim 135 \mathrm{kDa}$, consistent with the $\alpha$ subunit of the type 1 IGF receptor and at $\mathrm{Mr} \sim 250 \mathrm{kDa}$, consistent with the reduced form of the type 2 IGF receptor. Treatment with BMP-2 slightly increased the intensity of the $\mathrm{Mr} \sim 135-\mathrm{kDa}$ band (Fig. 1A). ${ }^{125} \mathrm{I}-\mathrm{IGF}-\mathrm{I}$ also
A

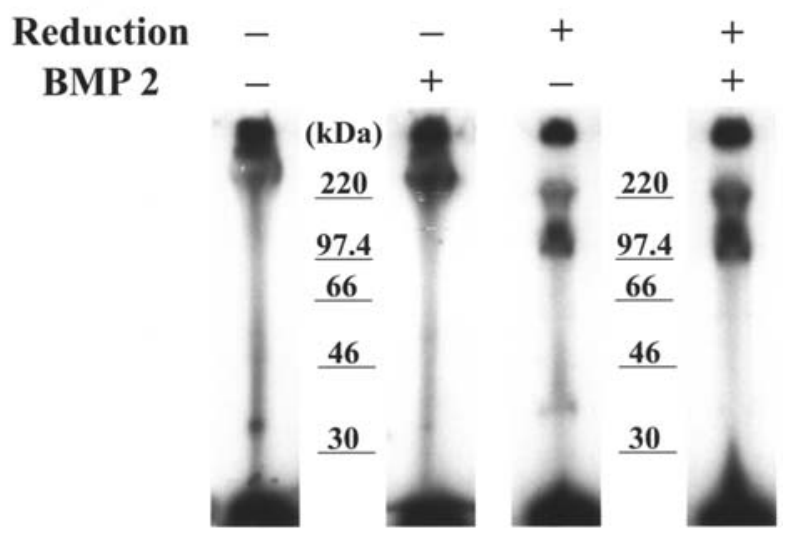

B

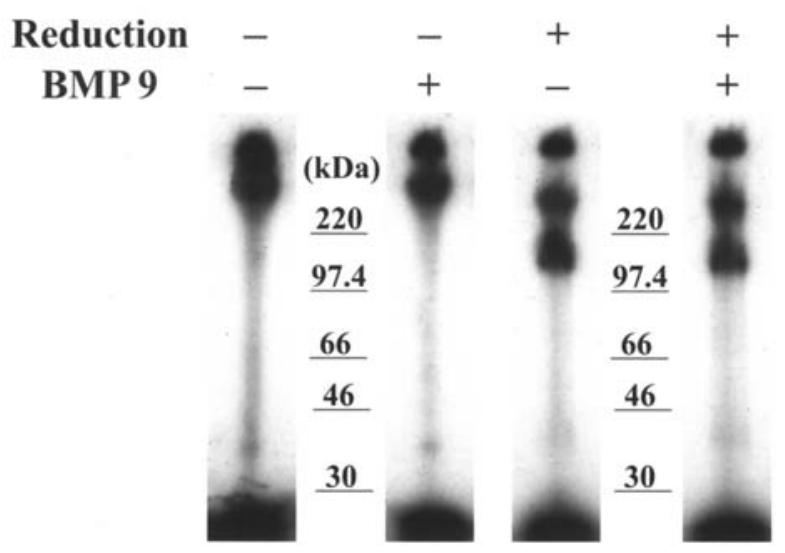

Figure 2. Affinity labeling of [ $\left.{ }^{125} \mathrm{I}\right]-\mathrm{IGF}-\mathrm{I}$ to growth plate chondrocytes with or without reduction by 2-mercaptoethanol. Labeling was without unlabeled ligand of cells treated with or without BMP-2 (A) or BMP-9 (B) and subsequently prepared with or without reduction by 2-mercaptoethanol. Molecular mass markers are shown in $\mathrm{kDa}$.

labeled an $\mathrm{Mr} \sim 43-\mathrm{kDa}$ band, consistent with binding to insulin-like growth factor binding protein-3. Treatment of chondrocytes with BMP-2 decreased the intensity of the $\mathrm{Mr} \sim 43-\mathrm{kDa}$ band. In contrast to BMP-2, BMP-9 did not increase the intensity of the $\mathrm{Mr} \sim 135-\mathrm{kDa}$ band and either had no effect on or increased the intensity of the $\mathrm{Mr} \sim 43-\mathrm{kDa}$ band (Fig. 2A).

${ }^{3}$ H-thymidine incorporation. BMP-2 alone had no consistent effect on DNA synthesis ( $\mathrm{p}>0.05)$. BMP-9 alone similarly did not affect DNA synthesis $(\mathrm{p}>0.05)$. In combination with IGF-I, graded concentrations of BMP-2 increased the stimulatory effect of IGF-I ( $\mathrm{p}=0.002)$ (Fig. 3A). In combination with IGF-I, BMP-9 similarly augmented the stimulatory effect of IGF-I ( $\mathrm{p}=0.010)$ (Fig. 3B).

\section{Discussion}

Several BMP family members regulate the differentiation of cartilage and the differentiated phenotype of chondrocytes. BMP-2 induces the chondrogenic differentiation of human multipotential mesenchymal cells (18), a clonal undifferentiated cell line (19) and mesenchymal cells (20). BMP-2 


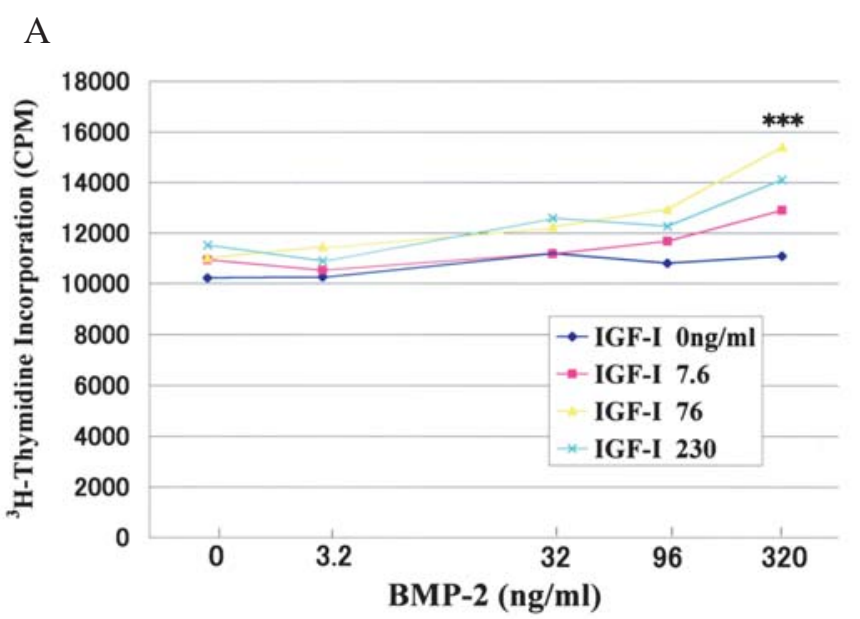

B

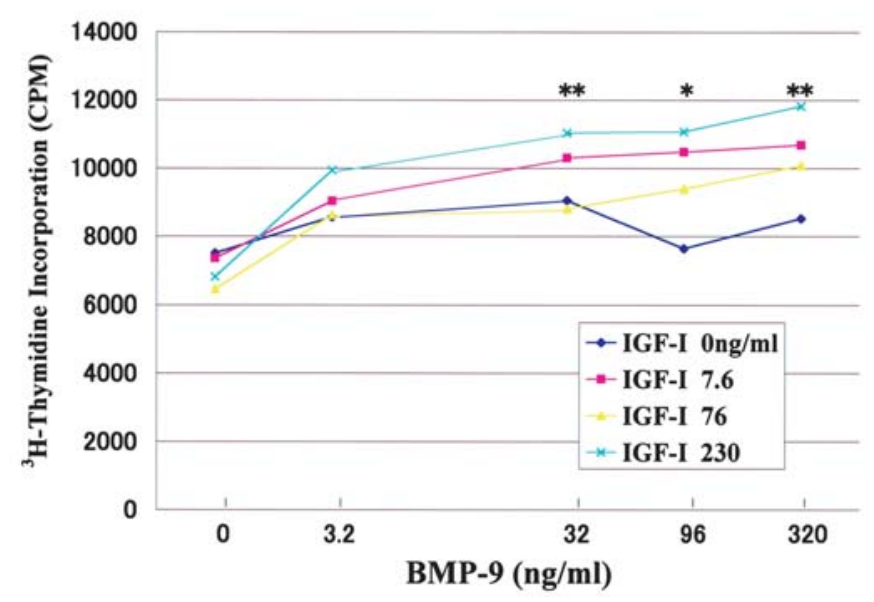

Figure 3. The effect of IGF-I with BMP-2 (A) or with BMP-9 (B) on thymidine incorporation by growth plate chondrocytes. Each data point represents the mean of three independent experiments (five replicates per experiment). Significant differences among the groups for each concentration of BMP-2 and BMP-9 are denoted by ${ }^{*} \mathrm{p}<0.05,{ }^{* *} \mathrm{p}<0.01$, and ${ }^{* * *} \mathrm{p}<0.001$.

and BMP-3 stimulate and maintain proteoglycan synthesis and enhance alkaline phosphatase activity in differentiated chondrocytes in vitro $(20,21)$. Only a few reports have addressed the function of BMP-9 (22) in cartilage. BMP-9, like BMP-2, stimulates alkaline phosphatase activity in a murine osteoprogenitor cell line $(22,23)$, and increases proteoglycan synthesis in bovine articular cartilage explants.

IGF-I has well-established mitogenic and anabolic effects on growth plate chondrocytes in vitro and has been shown to regulate skeletal growth in vivo. Despite the presumed importance of the BMPs and IGF-I in chondrocyte regulation, there has been, to our knowledge, no investigation of the interaction between the IGF and BMP families in the regulation of these cells. The present data suggest that BMP-2 and BMP-9 modulate IGF-I action in growth plate chondrocytes.

The cellular actions of IGF-I are mediated by binding to transmembrane IGF receptors (24). The type 1 IGF receptor is a heterotetrameric complex $(\sim 300 \mathrm{kDa})$ consisting of two extracellular $\alpha$ subunits $(\sim 135 \mathrm{kDa})$ and two transmembrane $ß$ subunits ( $\sim 90 \mathrm{kDa})$ joined by disulfide bonds. The complex migrates on SDS-PAGE at $\mathrm{Mr}>300 \mathrm{kDa}$ under non-reducing conditions and separates into $\sim 135-\mathrm{kDa} \alpha$ and $\sim 90-\mathrm{kDa} \beta$ subunits under reducing conditions. The type 2 IGF receptor is a monomer that contains intramolecular disulfide bonds, such that it migrates at $\mathrm{Mr} \sim 240$ and 260 under nonreducing and reducing conditions, respectively. IGF-I binds to both receptors, though with a higher affinity for the type 1 receptor. Most of the biological effects of IGF-I are thought to be mediated by the type 1 receptor (8). In the present kinetic studies, BMP-2 significantly increased IGF-I binding at 2 of the 4 concentrations tested. Although BMP-9 increased IGF-I binding in individual experiments (Fig. 1B), this effect was not statistically significant in multiple experiments. This lack of statistical difference may be due to interexperimental variation. In the present affinity labeling studies, BMP-2, but not BMP-9 appeared to increase IGF-I binding to the type 1 and possibly the type 2 IGF receptors. This difference could also reflect, at least in part, potential differences among the electrophoresis lanes.

The actions of IGF-I are modulated by the insulin-like growth factor binding proteins (IGFBPs), a family of 6 proteins that have affinities for IGF-I that may exceed those of the IGF receptors (10). Although IGFBP-2 to -5 have all been demonstrated to be present in human cartilage, IGFBP-3 and -4 are secreted in the greatest abundance by human chondrocytes in culture (9). IGFBP-3 may inhibit IGF binding to type 1 IGF receptor (25), but under some conditions may augment the effects of IGF-I.

BMPs exert their biological effect by interactions with cell surface receptors (26). BMP-9 receptors on HepG2 cells do not bind other members of the BMP or TGF- $B$ families, indicating a mechanism for binding specificity for BMP-9 (22). BMP-7, another osteogenic BMP, has been shown to increase the levels of IGFBP-3 and -5 in the conditioned medium (27) of human bone cells. BMP-7, alone or in combination with IGF-I, increased IGFBP-3 mRNA levels and reduced those of IGFBP-4, -5 , and -6 in osteoblastic cells (28). In the present study, the apparent decrease in IGFBP-3 observed in response to BMP-2 may reflect a difference between BMP-2 and BMP-7 or between osteoblastic cells and growth plate chondrocytes. The observation that BMP-2, but not BMP-9, reduced IGF-I binding to the $\sim 43-\mathrm{kDa}$ moiety is one of the few differences observed between BMP-2 and BMP-9.

Treatment with BMP-2, -3 , or -4 has been reported to increase thymidine incorporation by cultured chondrocytes (21). In contrast, Sailor et al (6) reported that BMP-2 did not alter articular chondrocyte proliferation. Using periosteal cells, Mayer et al (29) found that BMP-2 caused a timedependent stimulation of ${ }^{3} \mathrm{H}$-thymidine incorporation that peaked at $20 \mathrm{~h}$ after treatment and was lost after $30 \mathrm{~h}$. Erickson et al (30) reported that BMP-2 increased the incorporation of ${ }^{3} \mathrm{H}$-thymidine by both quiescent resting zone and growth zone growth plate chondrocytes. In nonquiescent cultures, BMP-2 increased that of resting zone cells, but not that of growth zone cells. Resting zone chondrocytes were more sensitive to the regulation of proliferation, differentiation, and matrix production.

In the present study, neither BMP-2 nor BMP-9 increased DNA synthesis. However, both BMP-2 and BMP-9 augmented 
the mitogenic action of IGF-I. This augmentation occurred at lower concentrations of BMP-9 than of BMP-2. In prior studies, epidermal growth factor (EGF) increased both IGF-I binding and IGF-I responsiveness in growth plate chondrocytes (31), and IGF-I enhanced the mitogenic effect of TGF- $ß 1$ and fibroblast growth factor (FGF) on these cells (32). Taken together, these data support the view that growth factor interaction may be an important mechanism of cell regulation, including the regulation of growth plate chondrocytes.

In conclusion, these data suggest that BMP-2 and BMP-9 have regulatory effects on the IGF axis. The data further suggest that the BMPs may modulate the IGF action via the type 1 receptor and/or IGF binding proteins. Future studies will be required to elucidate the cellular and molecular mechanisms by which these growth factor interactions are regulated.

\section{Acknowledgements}

This study was supported in part by NIH grant no. AR 31068 .

\section{References}

1. Trippel SB, Wroblewski J, Makower A-M, Whelan MC and Schoenfeld D: Regulation of growth-plate chondrocytes by insulin-like growth-factor I and basic fibroblast growth factor. J Bone Joint Surg 75-A: 177-189,1993.

2. Van Wyk JJ, Graves DC, Casella SJ and Jacobs S: Evidence from monoclonal antibody studies that insulin stimulates deoxyribonucleic acid synthesis through the type I somatomedin receptor. J Clin Endocrinol Metab 61: 639-643, 1985.

3. D'Ercole AJ: Expression of insulin-like growth factor-I in transgenic mice. Ann NY Acad Sci 692: 149-160, 1993.

4. Van der Eerden BC, Karperien M and Wit JM: Systemic and local regulation of the growth plate. Endocr Rev 24: 343-350, 2003.

5. Wozney JM and Rosen V: Bone morphogenetic protein and bone morphogenetic protein gene family in bone formation and repair. Clin Orthop 346: 26-37, 1998.

6. Sailor LZ, Hewick RM and Morris EA: Recombinant human bone morphogenetic protein-2 maintains the articular chondrocyte phenotype in long-term culture. J Orthop Res 14: 937-945, 1996.

7. Olney RC, Wang J, Sylvester JE and Mougey EB: Growth factor regulation of human growth plate chondrocyte proliferation in vitro. Biochem Biophys Res Commun 317: 1171-1182, 2004.

8. Nakae J, Kido Y and Accili D: Distinct and overlapping functions of insulin and IGF-I receptors. Endocr Rev 22: 818-835, 2001.

9. Tardif G, Reboul P, Pelletier JP, Geng C, Cloutier JM and Martel-Pelletier J: Normal expression of type 1 insulin-like growth factor receptor by human osteoarthritic chondrocytes with increased expression and synthesis of insulin-like growth factor binding proteins. Arthritis Rheum 39: 968-978, 1996.

10. Rajaram S, Baylink DJ and Mohan S: Insulin-like growth factor-binding proteins in serum and other biological fluids: Regulation and functions. Endocr Rev 18: 801-831, 1997.

11. De los Rios P and Hill DJ: Cellular localization and expression of insulin-like growth factors (IGFs) and IGF binding proteins within the epiphyseal growth plate of the ovine fetus: possible functional implications. Can J Physiol Pharmacol 77: 235-249, 1999.

12. Yamashita H, Ten Dijke P, Heldin C-H and Miyazono K: Bone morphogenetic protein receptors. Bone 19: 569-574, 1996.

13. Wang EA, Israel DI, Kelly S and Luxenberg DP: Bone morphogenetic protein-2 causes commitment and differentiation in C3H10T1/2 and 3T3 cells. Growth Factors 9: 57-71, 1993.
14. Wozney JM, Rosen V, Wang EA, et al: Novel regulators of bone formation: molecular clones and activities. Science 242: 1528-1534, 1988.

15. Luyten FP, Yu YM, Yanagishita M, Vukicevic S, Hammonds RG and Reddi AH: Natural bovine osteogenin and recombinant human bone morphogenic protein-2B are equipotent in the maintenance of proteoglycan in bovine articular cartilage explant cultures. J Biol Chem 267: 3691-3695, 1992.

16. Wang EA, Rosen V, Wozney JM, et al: Recombinant human bone morphogenic protein induces bone formation. Proc Natl Acad Sci USA 87: 2220-2224, 1990.

17. Trippel SB, Chernausek SD, Van Wyk JJ, Moses AC and Mankin HJ: Demonstration of type I and type II somatomedin receptors on bovine growth plate chondrocytes. J Orthop Res 6: 817-826, 1988.

18. Majumdar MK, Wang E and Morris EA: BMP-2 and BMP-9 promote chondrogenic differentiation of human multipotential mesenchymal cells and overcome the inhibitory effect of IL-1. J Cell Physiol 189: 275-284, 2001.

19. Aikawa T, Shirasuna K, Iwamoto M, et al: Establishment of bone morphogenetic protein 2 responsive chondrogenic cell line. J Bone Miner Res 11: 544-553, 1996.

20. Duprez DM, Coltey M, Amthor H, Brickell PM and Tickle C: Bone morphogenic protein-2 (BMP-2) inhibits muscle development and promotes cartilage formation in chick limb bud cultures. Dev Biol 174: 448-452, 1996.

21. Hiraki Y, Inoue H, Shigeno C, et al: Bone morphogenetic proteins (BMP-2 and BMP-3) promote growth and expression of the differentiated phenotype of rabbit chondrocytes and osteoblastic MC3T3 cells in vitro. J Bone Miner Res 6: 1373$1385,1991$.

22. Song JJ, Celeste AJ, Kong FM, Jirtle RL, Rosen V and Thies RS: Bone morphogenic protein-9 binds to liver cells amd stimulates proliferation. Endocrinology 136: 4293-4297, 1995.

23. Majumdar MK, Wang E, Morris EA: BMP-2 and BMP-9 promotes chondrogenic differentiation of human multipotential mesenchymal cells and overcomes the inhibitory effect of IL-1. J Cell Physiol 189: 275-284, 2001.

24. D'Ercole AJ: Insulin-like growth factors and their receptors in growth. Endocrinol Metab Clin North Am 25: 573-590, 1996.

25. Mohseni-Zadeh S and Binoux M: Insulin-like growth factor (IGF) binding protein-3 interacts with the type I IGF receptor; reducing the affinity of the receptor for its ligand: an alternative mechanism in the regulation of IGF action. Endocrinology 138: 5645-5648, 1997

26. Enomoto-Iwamoto M, Iwamoto M, Mukudai Y, et al: Bone morphogenetic protein signaling is required for maintenance of differentiated phenotype, control of proliferation, and hypertrophy in chondrocytes. J Cell Biol 140: 409-418, 1998.

27. Knutsen R, Honda Y, Strong DD, Sampath TK, Baylink DJ and Mohan S: Regulation of insulin-like growth factor system components by osteogenic protein-1 in human bone cells. Endocrinology 136: 857-865, 1995.

28. Yeh LC, Adamo ML, Olsen MS and Lee JC: Osteogenic protein-1 and insulin-like growth factor 1 synergistically stimulate rat osteoblastic cell differentiation and proliferation. Endocrinology 138: 4181-4190, 1997.

29. Mayer H, Scutt AM and Ankenbauer T: Subtle differences in the mitogenic effects of recombinant human bone morphogenetic proteins -2 to -7 on DNA synthesis on primary boneforming cells and identification of BMP-2/4 receptor. Calcif Tissue Int 58: 249-255, 1996.

30. Erickson DM, Harris SE, Dean DD, et al: Recombinant bone morphogenetic protein (BMP)-2 regulates costochondral growth plate chondrocytes and induces expression of BMP-2 and BMP-4 in a cell maturation-dependent manner. J Orthop Res 15: 371-380, 1997.

31. Bonassar LJ and Trippel SB: Interaction of epidermal growth factor and insulin-like growth factor- 1 in the regulation of growth plate chondrocytes. Exp Cell Res 234: 1-6, 1997.

32. O'Keefe RJ, Crabb ID, Puzas JE and Rosier RN: Effects of transforming growth factor-beta 1 and fibroblast growth factor on DNA synthesis in growth plate chondrocytes are enhanced by insulin-like growth factor-I. J Orthop Res 12: 299-310, 1994. 